\title{
The Analysis of the Problems in Business English Teaching Assessment System and Suggestions for Improvements
}

\author{
Guo Guihang ${ }^{1} \&$ Zhou Chen ${ }^{1}$ \\ ${ }^{1}$ School of English for International Business, Guangdong University of Foreign Studies, China \\ Correspondence: Guo Guihang, School of English for International Business, Guangdong University of Foreign \\ Studies, No.2 Baiyundadaobei, Guangzhou, China.
}

Received: June 3, 2019 Accepted: July 8, 2019 Online Published: July 10, 2019

doi: 10.5539/elt.v12n8p44 URL: https://doi.org/10.5539/elt.v12n8p44

\begin{abstract}
As an undergraduate program, Business English is still in the initial stage of development in China. It is a new inter-disciplinary and applied discipline, the teaching of which is practical and diverse. Teaching assessment is an important part of the curriculum teaching because it is beneficial for the teacher to obtain feedback, improve teaching quality and maintain the teaching foundation. It is an effective measure for students to find the most suitable learning methods, correct learning habits and enhance learning efficiency. Teaching assessment plays a macro-control role in the implementation of teaching activities and can ensure the realization of teaching effects. Most of the current assessments of Business English teaching is in line with the language test mode of college English. Their assessment of the students' Business English ability is conducted from the perspectives of using vocabulary, syntax and text. They only detect one of the students' comprehensive abilities, namely, language ability while ignoring the assessment of application ability and professional literacy as well as other capabilities. This paper conducts a questionnaire survey on sophomores, juniors, seniors, and students who have graduated majoring in Business English at Guangdong University of Foreign Studies and Hubei University, aiming at finding out problems in the current assessment system for Business English teaching. Based on the analysis of the problems, suggestions for establishing a new Business English teaching assessment system are proposed.
\end{abstract}

Keywords: business English, teaching assessment, formative assessment, reform

\section{Introduction}

In 2007, Business English was approved by the Ministry of Education to be a Bachelor of Arts program in universities. Since China's accession to the WTO, a large number of foreign companies have entered the Chinese market, coupled with the vigorous development of foreign trade, the demand for Business English talents is also increasing. Business English is a new type of English for Special Purposes (ESP) with strong professionalism the teaching of which is characterized by specialization, colloquialism and strong pertinence. Therefore, it is very important to improve the quality of Business English teaching. The establishment of a reasonable and effective Business English teaching assessment system serves as a necessary prerequisite for improving the quality of teaching, and a powerful guarantee for the realization of Business English teaching goals as well. It can not only help teachers to obtain teaching feedback, improve teaching methods and improve teaching quality, but also assist students to adjust their learning strategies and improve their learning efficiency. However, under the background of exam-oriented education, the assessment system of Business English teaching uses examinations as the only way of assessing and the results of examinations as assessing results, while some other important aspects such as abilities, attitudes and values of the students are not assessed. According to the national teaching standards, Business English teaching assessment should consist of both formative assessment and summative assessment. However, the application of formative assessment in Business English teaching still has a long way to go.

As an important part of Business English teaching, the establishment of a scientific and rational teaching assessment system is a necessary prerequisite for promoting the realization of Business English teaching goals. However, most of the current Business English teaching assessments continue to use the model of college General English teaching assessment which only focuses on students' Business English ability in the matter of vocabulary, syntax and text while ignoring the assessment of other capabilities such as the application of business knowledge and professional literacy. Such a teaching assessment system cannot fully achieve the goal 
of Business English teaching prescribed by the national standard. Due to the strong practicality of Business English as compared with general college English, it is more practical to adopt formative assessment. The integration of formative assessment and summative assessment in Business English teaching assessment is of high social value and practical significance.

To gain an insight into the existing problems in the assessment of Business English Teaching, a questionnaire survey was conducted in this study. Through the analysis of the results of survey, problems existing in the current Business English teaching assessment system were identified, and suggestions for establishing a new Business English assessment system are proposed accordingly.

\section{Literature Review}

Through the analysis of the current Business English teaching assessment system, Zhou and Tang (2007) put forward that the assessment standard and the assessment method of the current assessment system are too single. They further suggest that teaching assessment should include assessment of teachers and assessment of the students, with the former as a comprehensive assessment of teaching work of teachers, while the latter as the assessment of students' mastery of knowledge, ability and quality. Mo (2009) propose that the application of formative assessment to Business English teaching assessment system could help students to have a better understanding of their own advantages and disadvantages, to establish clear goals and to improve their interest in learning. By analyzing the differences between Business English and General English, Hu (2009) puts forward the idea that the assessment of Business English teaching should be taken in two forms, which are Standard Reference Form Test and Conventional Reference Test. Wang and Hua (2010) analyze the characteristics of Business English and the current assessment system of Business English teaching and propose that the current assessment system of Business English is only aimed at assessing student's mastery of professional knowledge, and usually only takes the result of the final test as the basis of assessment. This kind of assessment system cannot realize a reliable assessment of the actual ability of students, and will get students accustomed to learning by rote rather than attaching great importance to cultivating practical abilities. Based on the problems, they further propose that the current assessment system of Business English should be reformed from three perspectives: content, way and objective. After analyzing the current Business English teaching assessment system, Liu (2011) detects several problems in current assessment system of Business English, such as lack of integrity, lack of interaction and lack of subsequent ductility. She then proposes that formative assessment should be integrated into the Business English teaching assessment system, and the students should be assessed based on the skills stipulated in the Business English Syllabus. Chang (2013) finds that the current Business English teaching assessment system is usually based on the summative assessment, with students' mastery of knowledge being assessed by referring to the results of final exams. This kind of assessment system is easy to lead to the students' neglecting of class. In addition, she also proposes that the non-testability assessment should be adopted in Business English teaching assessment with self-assessment and questionnaire survey as supplement. Quan (2015) proposes that the assessment system of Business English based on formative assessment will help the students to enhance their enthusiasm, confidence and interest in studying. After analyzing the current assessment system of Business English, Hu (2015) finds that there exist two problems: the application persistence of the current assessment system cannot be guaranteed, and the assessment of knowledge points is far from enough. She further puts forward the idea that the assessment system should be established by taking the actual needs of students as well as actual needs of social work into consideration. Lu (2015) states that in order to realize the effectiveness of Business English teaching, the assessment system of Business English teaching must be based on formative assessment and the teaching reform and academic exchange platform should be established among schools. Wu (2016) proposes that Business English teaching assessment should be based on formative assessment and should be constructed from the perspective of assessment content, assessment method, assessment standard and assessment process.

Through the review of the above literature available in China, we can find that most of those scholars have detected the lack of formative assessment in the assessment system of Business English teaching. However, these studies are based on qualitative analysis rather than empirical research. In addition, the researches related to the assessment system of Business English teaching are far from enough and still has a long way to go. In order to make up for this deficiency, this paper will make an empirical analysis of the problems existing in the assessment of Business English teaching by means of a questionnaire survey, and then propose suggestions for improvement based on the results of the analysis.

\section{Theoretical Foundation}

Domestic and foreign scholars' researches on teaching assessment of Business English involve many fields, such 
as the definition, classification, needs analysis, curriculum design. The theoretical framework of this study mainly includes three aspects, which are the category of teaching assessment, needs analysis and skill-based approach. As for the category of teaching assessment, it facilitates our understanding of the practical teaching assessment. As for needs analysis, it is integrated into the development of Business English students and helps to meet their learning needs accordingly. As for skill-based approach, it helps to identify the skills needed for Business English learners. The combination of the three theories above is conducive to the establishment of a practical and effective teaching assessment system for Business English.

\subsection{The Category of Teaching Assessment}

The concept of "formative assessment" was first proposed by the American philosopher Shriver in a course study. In the paper named Assessment Method, he proposed that there existed two types of education assessment, namely formative assessment and summative assessment. According to the definition made by him, formative assessment occurs in the process of curriculum teaching and education activities, while summative assessment focuses on the results of teaching activities. Since then, many scholars at home and abroad have begun to study the formative assessment. American educationist Broome believes that formative assessment is a systematic assessment, the purpose of which is not to grade or identify learners, but to obtain teaching feedback and improve the quality of education and teaching. Through formative assessment, teachers can get feedback in time, modify teaching methods, and promote effective learning (1971). According to Gepps (1994), formative assessment refers to the assessment of student's work or performance to shape and improve student's ability. From the perspective of Torrance and Price (2001), formative assessment is a continuous process in which students monitor their personal progress (Part, 1998). Hurkey (2002) proposes that formative assessment is a process that tracks students' progress and it focuses on finding ways to help realize it. Jack (2008) proposes that formative assessment is adopted to provide teachers with feedback of the current understanding and skill development of students and finally helps to determine the way forward. Harlem (2005) regards formative assessment as "assessment for learning" and summative assessment as "assessment of learning". From the definition mentioned above, we can draw the conclusion that formative assessment refers to the assessment of students' knowledge, level of ability development, and attitude towards learning in the classroom during the teaching process. This kind of assessment often takes place throughout the entire teaching process and is timely. The formative assessment can not only improve teachers' teaching efficiency, but also develop differentiated assessment criteria based on student differences, promote students' development in all aspects, stimulate students' interest in learning, and cultivate students' self-learning ability.

Summative assessment refers to the judgment of the effectiveness of education in the end of educational activities. The most typical form of summative assessment is examinations. The differences between summative assessment and formative assessment are mainly reflected in six aspects: assessment purpose, assessment object, assessment subject, assessment content, assessment method, and assessment time. The formative assessment is aimed at assessing the teaching effect, analyzing the teaching problem and continuously modifying it, while the summative assessment is aimed at grasping information about the students' learning status quo. Formative assessment focuses on the learning process, while summative assessment emphasizes learning outcomes. The subject of formative assessment includes students, parents and teachers, and the subject of summative assessment exclusively refers to the teacher. Formative assessment can be taken as a assessment of knowledge, skills, learning attitudes, teaching strategies, etc., while summative assessment only assess how students grasp knowledge. Formative assessment methods are diverse, including observations, questionnaires, and other forms, while summative assessments usually only depend on exams or tests. Formative assessment occurs throughout the entire learning process and is irregular, while summative assessment usually occurs when the learning process comes to an end.

\subsection{Needs Analysis}

Needs analysis was proposed in the mid-1970s after the ESP learners' purpose was recognized. According to Braine (2001), it is almost unthinkable to ignore the needs of the learners in designing English language curriculum. Many scholars have defined need analysis from different perspectives, such as the study or job requirements of the learners (Widdowson, 1978), what the user-institution or society at large regards as necessary or desirable to be learned from a program of language instruction (Mountford, 1981) and different models for needs analysis have been proposed, such as the target situation analysis (TSA) by John Munby (1978), target needs analysis and learning needs analysis by Hutchinson and Waters (1987), Brindley's model (1989), Dudley-Evans's (1998) model. According to Robinson (1987), ESP is established on the basis of the need analysis of learners. What's more, in teaching ESP, it is necessary to firstly investigate and analyze the needs of learners, including social needs and personal needs (Long, 2005). Therefore, we can see that needs analysis can 
be regarded as the foundation of ESP teaching. This study adopts Hutchinson \& Waters' model which divides needs analysis into two aspects: the target needs analysis and learning needs analysis. Only by conducting needs analysis can the real needs and intentions of the learners be determined and a practical teaching assessment be established thereby.

\subsection{Skill-Based Approach}

According to Coffey and West (1994), authenticity should be the top consideration in designing ESP material for the purpose of cultivating the skills. Different from General English, the concept of skill is expanded. By referring to Teaching Requirements for Business English BA Program in Colleges and Universities (Trial), or hereafter Teaching Requirements, the specialized knowledge and skills of Business English include four parts: language knowledge and skills, business knowledge and skills, intercultural communication competence and humanistic quality. Therefore, the teaching assessment of Business English should put more emphasis on the real communicative competence of students in business environment rather than the traditional language skills of reading, writing, listening and speaking.

\section{Research Questions and Method}

\subsection{Research Questions}

This study, from the perspective of ESP, together with the previous studies and case study, aims at answering the following two questions: 1. What are the problems existed in current teaching assessment system of Business English? 2. How to establish a more practical teaching assessment system of Business English?

\subsection{Research Method}

This study adopts questionnaire as the research method to better probe into the problems existed in the current assessment system of Business English. Questionnaires are designed to discover the viewpoints of students in Guangdong University of Foreign Studies (GDUFS) and Hubei University because these two colleges are of the same educational status and the author have studied there. To ensure the authenticity and efficiency of the survey, questionnaires are distributed by the APP named SO JUMP. There are altogether 9 questions, the first two are concerned with the basic information of the participants to ensure the objectivity and fairness of this study, and the other seven questions are designed according to the relevant content of Teaching Requirements. There are altogether 128 valid questionnaires collected after excluding the invalid ones. The results are shown in the following part.

\section{Results of Survey and Discussion}

Due to the fact that currently the freshmen majored in Business English may not fully understand the Business English professional assessment system, the survey targets only at the sophomores, juniors, seniors, the undergraduates and postgraduate students of Guangdong University of Foreign Studies and Hubei University. There are 128 questionnaires recollected and most of which are finished by the undergraduates and postgraduate students who have the best understanding of the assessment system. For the analysis of the questionnaire, this paper uses the Likert four-point and five-point measurement methods. The four-point Likert measurement method is used for questions 4, 5, 6, and 7. The four options correspond to 5, 3.75, 2.5, and 1.25 from small to large according to the attitude intensity. For item 3, the Likert five-point measurement method is used. According to the attitude intensity from small to large, the options correspond to 5, 4, 3,2, and 1 respectively. Therefore, the scores of the five questions are from 1 to five. The ultimate results are as followed:

3. Are you satisfied with the current Business English teaching assessment system?

\begin{tabular}{lll}
\hline options & scores & percentages \\
\hline A. Very satisfied & 6 & $5 \%$ \\
B. Satisfied & 20 & $16 \%$ \\
C. Basically satisfied & 26 & $20 \%$ \\
D. Basically not satisfied & 39 & $30 \%$ \\
E. Not satisfied at all & 37 & $29 \%$ \\
Total & 128 & $100 \%$ \\
\hline
\end{tabular}


4. Do you think that the assessment system of Business English teaching in universities can make a reasonable inspection of your real knowledge or skills?

\begin{tabular}{lll}
\hline options & scores & percentages \\
\hline A. Absolutely yes & 5 & $4 \%$ \\
B. Basically yes & 12 & $9 \%$ \\
C. Basically not & 71 & $54 \%$ \\
D. Not at all & 40 & $33 \%$ \\
Total & 128 & $100 \%$ \\
\hline
\end{tabular}

5. Are the assessment of Business English teaching in the University which you are studying in or have graduated from based on the final exam results as a final basis?

\begin{tabular}{lll}
\hline options & scores & percentages \\
\hline A. Absolutely yes & 52 & $41 \%$ \\
B. Basically yes & 49 & $38 \%$ \\
C. Basically no & 23 & $18 \%$ \\
D. Not at all & 4 & $3 \%$ \\
Total & 128 & $100 \%$ \\
\hline
\end{tabular}

6. Is the Business English teaching assessment in the University which you are studying in or have graduated from beneficial or enlightening for your study after you know the assessment result?

\begin{tabular}{lll}
\hline options & scores & percentages \\
\hline A. Absolutely yes & 8 & $6 \%$ \\
B. Basically yes & 24 & $19 \%$ \\
C. Basically no & 57 & $45 \%$ \\
D. Not at all & 39 & $30 \%$ \\
Total & 128 & $100 \%$ \\
\hline
\end{tabular}

7. Does the Business English teaching assessment in the University which you are studying in or have graduated from assess the students' abilities of applying the knowledge into practical use?

\begin{tabular}{lll}
\hline options & scores & percentages \\
\hline A. Absolutely yes & 7 & $6 \%$ \\
B. Basically yes & 37 & $29 \%$ \\
C. Basically no & 53 & $41 \%$ \\
D. Not at all & 31 & $24 \%$ \\
Total & 128 & $100 \%$ \\
\hline
\end{tabular}

8. Is there any other form except from exams for Business English teaching assessment in the University which you are studying in or have graduated from?

\begin{tabular}{lll}
\hline options & scores & percentages \\
\hline A. Yes & 49 & $38 \%$ \\
B. No & 79 & $62 \%$ \\
Total & 128 & $100 \%$ \\
\hline
\end{tabular}


9. Is there any subject except from teachers for Business English teaching assessment in the University which you are studying in or have graduated from?

\begin{tabular}{lll}
\hline options & scores & percentages \\
\hline A. Yes & 3 & $2 \%$ \\
B. No & 125 & $98 \%$ \\
Total & 128 & $100 \%$ \\
\hline
\end{tabular}

By using Likert four-point and five-point measurement methods, the scores of the problems three to seven are shown in the following table.

Table 1. Scores of Question 3-7 of the Questionnaire

\begin{tabular}{ll}
\hline Question & Scores (out of 5') \\
\hline Question 3 & 2.38 \\
Question 4 & 2.30 \\
Question 5 & 3.9625 \\
Question 6 & 2.512 \\
Question 7 & 2.7125 \\
\hline
\end{tabular}

From the score of question 3, we can see that the students are not satisfied with the current Business English teaching assessment system. From the final score of question 4, we can see that current Business English students think that the Business English teaching assessment system cannot effectively assess their actual knowledge or the actual situation of skills training. From the final score of question 5, it can be seen that from the perspective of Business English majors, the scores of the final examination account for a large proportion of the final Business English teaching assessment results. From the final score of question 6, we can see that, for Business English majors, the assessment result of the final Business English major teaching has little incentive or help for their learning after they know the results. From the final score of question 7, we can see that Business English majors think that Business English assessment system attaches great importance to the students' mastery of the knowledge, while the assessing of their skill of applying knowledge is often ignored.

There are 22 additional answers collected for question 8. According to the 22 answers, we can see that in addition to the examinations, there are mainly two types of assessing ways which are PPT presentations and case studies. The final results of question 9 showed that there are three people indicating that the subject of their school's Business English teaching assessment is not only their teachers, but the three did not fill out specific answers.

\section{Current Status of Business English Teaching Assessment System and Existing Weaknesses}

In 2009, Teaching Requirements proposed to use formative and summative assessment methods to fully assess students' ability of applying English. This requirement also applies to Business English teaching assessment. However, due to the fact that the university's assessment of students' mastery of knowledge is still largely based on the students' achievements. There is still a long way to go before the formative assessment is truly integrated into Business English teaching.

At present, after the analysis of the questionnaire results, the problems of the assessment system for Business English majors in colleges and universities can be summarized as follows:

Firstly, the assessment results of Business English teaching are generally announced after the end of the semester. This practice runs counter to the goal of the Business English teaching assessment system as the purpose of assessment is to understand the deficiencies in the students in their learning process and to promote better learning by changing teaching methods. However, the current assessment system seems to be aimed at ranking student according to their test scores. The problems found after the assessment have not been further studied and solved. Such teaching assessment is only a form without any practical results.

Secondly, the current assessment system of Business English fails to realize continuity and timeliness. Most course teachers still focus on examinations for students and do not conduct serial analysis on the basic content of 
Business English classroom teaching. Students can obtain high scores by learning by rote before the exam. This practice fails to examine students' actual abilities. Instead, students are overly concerned with book knowledge while neglecting the cultivation of practical abilities or exploring spirits which runs counter to the real learning needs of the students and the skill-based approach of Business English. Therefore, students cannot really understand the essence of Business English classroom knowledge. Due to the lack of mastery of a comprehensive English classroom thinking, students cannot truly use what they have learned after graduation. In addition, it is often the case that only one or two tests are conducted every semester. Therefore, the assessment results lack credibility and cannot truly reflect the knowledge mastery level or skill level of students.

Thirdly, the assessment method is single. At present, there are mainly two methods adopted for Business English teaching assessment: classroom presentation and final exam. It seems that the classroom performance and final exam results are representative of the quality of teaching, while neglecting the assessment of teaching objectives, skill training, teaching quality, teachers' quality, teaching conditions and other aspects. The current single assessment method cannot truly reflect the quality of teaching and student learning, and thus cannot help the teachers or the students to find out the omissions and make up for the deficiencies.

Fourthly, the assessment subject is single. In most cases, the subject of current Business English teaching assessment system is the teacher, and the student is only the object of assessment. Due to the lack of self-assessment by students themselves and mutual assessment among students, this assessment system is not beneficial for students to have interaction, cultivate learning initiative, good study habits and correct learning attitude.

\section{Establishing of a New Business English Teaching Assessment System}

Establishing a scientific and reasonable assessment system for Business English teaching not only helps to improve the quality of Business English teaching, but also promotes the development of Business English talents. This paper analyzes the existing problems in the current Business English teaching assessment system, and believes that the current Business English teaching assessment system should be reformed from the following aspects:

\subsection{Improving the Diversity of Business English Teaching Assessment Forms}

The assessment of current Business English teaching is mainly based on the results of students' final exam. This assessment method can easily lead students' being tired of study, not paying attention to classroom learning, skipping class, and cheating in exams. In order to reduce the occurrence of student absenteeism, many teachers use formative assessment methods such as random roll call or questioning in class. However, these methods can not eliminate students' blundering emotions or contempt for classroom teaching. Some teachers divide students into several groups to conduct case studies to test students' mastery of knowledge and take the performance of group presentations as part of the final assessment results. Although this formative assessment method has improved students' participation to a certain extent and is conducive to improving students' practical application of knowledge. However, due to the limited time in class, teachers usually choose one group to do presentation in every class which will be hard to mobilize the enthusiasm of other students who do not need to participate in. And in many cases, due to lack of preparation before class, many students often find it hard to understand the content of the other groups' presentations. Therefore, various forms of formative assessment such as classroom presentations, seminars, project design, and case tracking can be integrated into the Business English teaching assessment system to truly realize the overall value of formative assessment.

\subsection{Reforming the Content of Business English Teaching Assessment System}

The traditional Business English teaching assessment system mainly focuses on students' mastery of textbook knowledge or knowledge imparted by the teachers. Through the need analysis of the Business English students and taking the skill-based approach of Business English into consideration, we know that they aim at being interdisciplinary and applied talents who have solid foundation in English and international perspective and humanistic qualities, mastering basic theories and knowledge such as linguistics, economics, management and law, familiar with the rules and practices of international business and who are equipped with practical ability to apply English skills, business practice skills, cross-cultural communication skills, critical and creative capabilities. Therefore, the new Business English teaching assessment system should pay more attention to formative assessment which not only assess students' mastery of knowledge, but also examine students' practical ability to use knowledge. For example, after learning the principle and related professional knowledge of formulating balance sheet in the Accounting class, in order to cultivate students' practical ability, teachers can use the real company's balance sheet to examine students' actual analysis ability and knowledge application ability. 


\subsection{Reforming the Subject of the Business English Teaching Assessment System}

The current Business English teaching assessment system mainly takes teachers as the subject of assessment. However, this assessment method is too simple because the teachers are not always with the students, they cannot accurately assess the student's true learning attitude, or learning ability. The subject of the new Business English teaching assessment system should include several aspects, students' self-assessment, mutual assessment among students, assessment of internship companies. Through students' self-assessment, students can reflect on their own deficiencies in learning needs and skills, then resort to self-criticism and self-correction. As we know, those closely involved cannot see as clearly as those outside, mutual assessment among students can help other students recognize their own deficiencies or problems, help others to make progress, and achieve positive interaction among the students. At the same time, through the assessment of other students, students' awareness of responsibilities has improved, and it helps students reflect on their own problems. Through the assessment made by the internship companies, students' knowledge or skills can be examined and they can be fully aware of whether they have met the needs of the working environment. By increasing the subjects of the assessment system, the comprehensiveness and fairness of the assessment results can be improved.

\subsection{Establishing Clear, Actionable Criteria of Assessment}

The current Business English teaching assessment system does not clearly define the assessment content, assessment form, appraiser, assessment frequency, assessment hierarchy, or assessment module, which can easily lead to lack of continuity, accuracy, and fairness in the assessment. Since the new Business English teaching assessment system pays more attention to formative assessment, a variety of assessment methods will be used to track the implementation of teaching objectives in the whole process of teaching. Therefore, the importance of formulating clear and operable assessment standards becomes even more prominent. According to the syllabus, Business English teaching assessment is mainly divided into two layers: knowledge layer and skill layer; the assessment content includes four parts: English knowledge and skills, business knowledge and skills, cross-cultural communication skills and humanistic qualities. Except from the traditional written test of the summative assessment, a variety of formative assessment methods should also be included; The subject of assessment should be changed from only teachers to the combination of teachers, students, internship companies, and other subjects; the assessment frequency should be set according to the specific course requirements, for instance, the frequency of the assessment of knowledge may be higher; while for the assessment of the skill, the frequency may be lower. At the same time, the assessment system should also have a clear assessment scale in order to achieve an accurate and fair assessment of the students' actual mastery of skills and the extent to which they meet their leaning needs.

\section{Conclusion}

According to the Teaching Requirements, for the purpose of fully assessing students' ability of applying English, the assessment system for Business English teaching should use a combination of formative and summative assessments. However, according to the survey, we find that the assessment system of Business English teaching in colleges and universities still largely relies on the summative assessment while ignoring the importance of formative assessment. The current Business English assessment system mainly has the following problems: lack of continuity and timeliness, low credibility, single assessment subject and assessment content. As the integration of formative assessment in the current assessment system of Business English teaching can improve the quality and the effectiveness of teaching, and better assess whether the students have mastered certain skills and met their leaning needs. Therefore, in the current Business English teaching assessment system, the integration of formative assessment is an inevitable trend in the reform of Business English teaching assessment system. Based on the problems found above, this article proposes the following suggestions for the establishment of a new assessment system for Business English teaching: First, to improve the diversification of Business English teaching assessment forms; Second, to reform the contents of assessment of Business English teaching assessment system; Third, to reform the subject of the assessment system of Business English teaching; Last, formulate clear and operable assessment criteria. The establishment of a scientific and reasonable Business English teaching assessment system not only helps improve the quality of Business English teaching, but also promotes the development of Business English talents and promotes the successful completion of Business English teaching goals as stipulated in the syllabus.

\section{Acknowledgements}

This research was supported with funds from Guangdong University of Foreign Studies under the provincial research project of the Career Development Strategies and Practices for Business English Teachers Under the Guide of National Criteria for Teaching Quality of Undergraduate Programs. The support is gratefully 
acknowledged.

\section{References}

Bloom. (1989). Educational Evaluation. East China Normal University Press.

Braine, G. (2001). Twenty years of needs analyses: Reflections on a personal journey. In J. Flowerdew, \& M. Peacock (Ed.) Research Perspectives on English for Academic Purposes. Cambridge: Cambridge University Press.

Brindley, G. Z. (1989). The role of needs analysis in adult ESL program design. In R. K. Johnson (Ed.), The second language curriculum. Cambridge: Cambridge University Press.

Chen, Y. K. (1999). Educational Evaluation. Beijing: People's Education Press. https://doi.org/10.1080/ 09500799908666948

Chen, Z. M., \& Wang, L. F. (2009). Teaching Requirements for Business English BA Program in Colleges and Universities (Trial). Beijing: Higher Education Press.

Coffey, B. (1984). State of the art article-ESP: English for specific purposes. Language Teaching. https://doi.org/10.1017/S0261444800010405

Department of Higher Education, Ministry of Education. Requirements for College English Teaching (Trial). (2004). Beijing: Tsinghua University Press.

Dudley-Evans, T., \& St John, M. J. (1998). Developments in ESP. Cambridge: Cambridge University Press.

Egon, G. G., \& Yvonna, S. L. (1989). Fourth Generation Evaluation. Newbury Park, Calif: Sage public-actions.

Guo, L., \& Hu, X. L. (2005). Discussion on the Effectveness of Formative Assessment in English Teaching. Sun Yatsen University Forum, 25(6), 34-35.

Harlen, W., \& James, M. (1997). Assessment and learning: differences and relationships between formative and summative assessment. Assessment in Education: Principles, Policy \& Practice, 4(3), 365-379. https://doi.org/10.1080/0969594970040304

Hood, S. (2004). Appraising Research: Taking a Stance in Academic Writing. University of Sydney.

$\mathrm{Hu}$, J. (2009). Some Thoughts on Improving the Teaching Assessment Methods of Business English. Journal of Educational Institute of Taiyuan University, 27(3), 36-39.

$\mathrm{Hu}, \mathrm{Y}$. (2015) Formative and Summative Assessment System for Business English Teaching. English on. Campus, 41-42.

Hutchinson, T., \& Waters, A. (1987). English for Specific Purposes. Cambridge: Cambridge University Press. https://doi.org/10.1017/CBO9780511733031

Hunston, S., \& Thompson, G. (2000). Assessment in Text: Authorial Stance and the Construction of Discourse. New York: Oxford University Press.

Jan, M. F. (1999). Enlightening Multiple Intelligence Papers. Taipei: National Taiwan Normal University Press.

Liu, Q. C. (2011). Construction of Formative Assessment System of Business English "MHS" Model in Higher Occupational Colleges. Journal of Huzhou Vocational and Technological College, 85(3), 86-88.

Lin, W. (2017). The Application of Formative Assessment in Business English Teaching. Journal of Jilin TV and Radio University, 181(1), 17-18.

Long, M. H. (2005). Second Language Needs Analysis. Cambridge: Cambridge University Press. https://doi.org/10.1017/CBO9780511667299

Luo, S. Q. (2003). A Study on Formative Assessment of English Classroom Teaching. Foreign Language Teaching and Research Press.

Lv, X. X. (2015). Construction of Teaching Assessment System for Business English Major Based on Teaching Effectiveness. Chinese \& Foreign Entrepreneurs, 498(6), 221-225.

Mo, X. R. (2009). Exploration and Application of Formative Assessment of Business English Visual-Audio-Speaking. Journal of Shandong Business English Vocational and Technological College, 9(4), 47-49.

Mountford, A. (1981). The what, the why and the way, in Aupelf/Goethe Institute/British Council (1).

Munby, J. (1978). Communicative Syllabus Design. Cambridge: Cambridge University Press. 
Quan, Q. Y. (2016). Formative Assessment of Business English Courses in Independent Undergraduate Colleges and Universities on the Cultivation of Students' Self-regulated Learning Ability. Management \& Technology of SME, 4, 182.

Robinson, P. C. (1991). ESP Today: A Practitioner's Guide. New York: Prentice Hall.

Scriven, M. (1991). Beyond Formative and Summative Evaluation. In M. W. Mclaughlin, \& E. D. C. Phillips (Eds.), Evaluation and Education: A Quarter Century. Chicago: University of Chicago Press.

Torrance, H., \& Pryor, J. (2001). Developing Formative Assessment in the Classroom: Using Action Research to Explore and Modify Theory. British Educational Research Journal, 27. https://doi.org/10.1080/ 01411920120095780

Wang, D. J., \& Guo, W. N. (2009). Pedagogy. Beijing: People’s Education Press.

Wang, G., \& Hua, N. (2010). Reform of Business English Teaching Mode and Assessment Mode in Higher Occupational Colleges. Kaoshi Zhoukan, 54, 21-23.

West, R. (1994). State of the art article-Needs analysis in language teaching. Language Teaching, 27. https://doi.org/10.1017/S0261444800007527

Widdowson, H. (1978). Teaching Language as Communication. Oxford: Oxford University Press.

\section{Copyrights}

Copyright for this article is retained by the author(s), with first publication rights granted to the journal.

This is an open-access article distributed under the terms and conditions of the Creative Commons Attribution license (http://creativecommons.org/licenses/by/4.0/). 